\title{
Fossil karst in the Jurassic of the Kościuszko Mound in Kraków (southern Poland)
}

\author{
Antoni WÓJCIK ${ }^{1, *}$, Małgorzata GARECKA ${ }^{1}$, Barbara OLSZEWSKA ${ }^{1}$ and Marcin WÓDKA ${ }^{1}$ \\ 1 Polish Geological Institute - National Research Institute, Carpathian Branch, Skrzatów 1, 31-560 Kraków, Poland
}

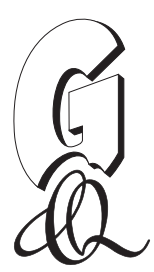

Wójcik, A., Garecka, M., Olszewska, B., Wódka, M., 2015. Fossil karst in the Jurassic of the Kościuszko Mound in Kraków (southern Poland) Geological Quarterly, 59 (1): 61-70, doi: 10.7306/gq.1204

\begin{abstract}
Study of four boreholes (each $100 \mathrm{~m}$ deep) drilled in St. Bronisława Hill (part of the horst of the Wolski Forest, Kraków) indicates that the Oxfordian limestone is interbedded by claystones with calcareous rubble (detritus) filling fossil karst forms. The claystones, locally showing planar stratification, contain assemblages of Late Cretaceous (Campanian-Maastrichtian) foraminifers. Middle Miocene planar laminated limestones have also been found in cavities formed in the Middle Oxfordian limestones. Miocene deposits of this type, filling the fossil karst, were not previously known from the area of Kraków. Both the Upper Cretaceous and Middle Miocene deposits document probably marine sedimentation that resulted in the filling of the karst system. This type of karst was probably formed before the transgression of the Late Cretaceous sea, and before the transgression of the Middle Miocene sea on the area of the present-day horst of the Wolski Forest.
\end{abstract}

Key words: southern Poland, Kraków Upland, karst, calcareous nannofossils.

INTRODUCTION

The Kościuszko Mound is located in the southern part of the Kraków Upland (southern Poland), in the western part of Kraków. It consists of Upper Jurassic limestones and is characterized by the occurrence of horsts and grabens (Gradziński, $1962,1972)$ reflected in the contemporary relief. Horsts appear as isolated hills, and grabens as depressions. The example of an elevation is the horst of the Wolski Forest (Fig. 1), also referred to as the Sowiniec Horst (Tyczyńska, 1968). Its eastern element is St. Bronisława Hill where the Kościuszko Mound is situated. A set of boreholes were drilled in the immediate vicinity of mound, of which four were $100 \mathrm{~m}$ deep (Figs. 2 and 3). The purpose of the boreholes was to recognize the base of the Kościuszko Mound and the geological structure of the area before designation of a tunnel on the so-called "Zwierzyniecka route" (Kos et al., 2013). The aim of this study was to investigate sediments filling fossil karst forms in this area. Results of the boreholes provided new interesting data concerning the karst development and the geological structure of the area, as well as pointed out to alternative options of interpretations of issues associated with the occurrence of younger sediments among Jurassic carbonate rocks in the area of Kraków.

\section{* Corresponding author, e-mail: antoni.wojcik@pgi.gov.pl}

Received: May 15, 2014; accepted: September 17, 2014; first published online: November 24, 2014

\section{GEOLOGICAL SETTING}

The dominant role in the geological structure of the southern part of the Kraków Upland is played by Upper Jurassic limestones (up to 200 m thick; Rutkowski, 1993). During the Cretaceous, Paleogene and Miocene, they were repeatedly emerged and eroded. This is documented by unconformably lying Albian, Cenomanian, Turonian, Maastrichtian and Neogene sediments (Gradziński, 1962). The sequence was described, among others, from the Bonarka Quarry (Bromley et al., 2009). Karst formations occur within the Jurassic limestones, some of them are filled with younger deposits (Gradziński, 1962; Głazek, 1989; Felisiak, 1992). In the area of Kraków, Upper Jurassic limestones form characteristic horsts. Depressions between the horsts are filled with thick Miocene sediments (Fig. 4).

So far, there are only few geological data concerning the nearest area to the Kościuszko Mound. The most important information was given by Gradziński (1972); it is also included in publications related to the geological maps of the area (Rutkowski, 1993; Felisiak et al., 2005; Gradziński, 2009). Deposits of the Miocene transgression were found closest to St. Bronisława Hill, and described by Gradziński (1962) Felisiak (1992) and Gradziński et al. (1995). The oldest of them are considered to be marine oyster limestones occurring under the Norbertine Monastery (Gradziński, 1962), and caliche-type deposits found both above and below the oyster limestone (Gradziński et al., 1995). Quaternary sediments, mainly loess from the "Spadzista street" site, were described by Łanczot et al. (2013). In the study area, two caves have been discovered so far NW of the Kościuszko Mound (Słobodzian, 2011): "Schronisko pod Klasztorem Norbertanek" (Baryła and Szelerewicz, 2011) and "Kawerna pod Fortem Kościuszko", 


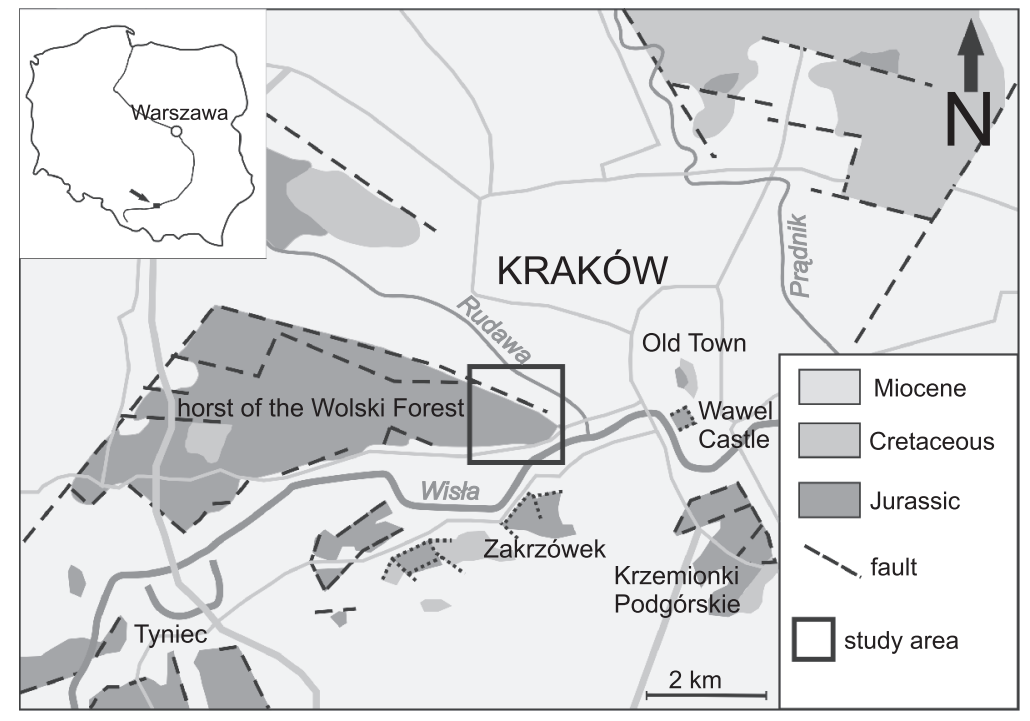

Fig. 1. Location of the study area on the map of main horst elements (after Gradziński, 2009)

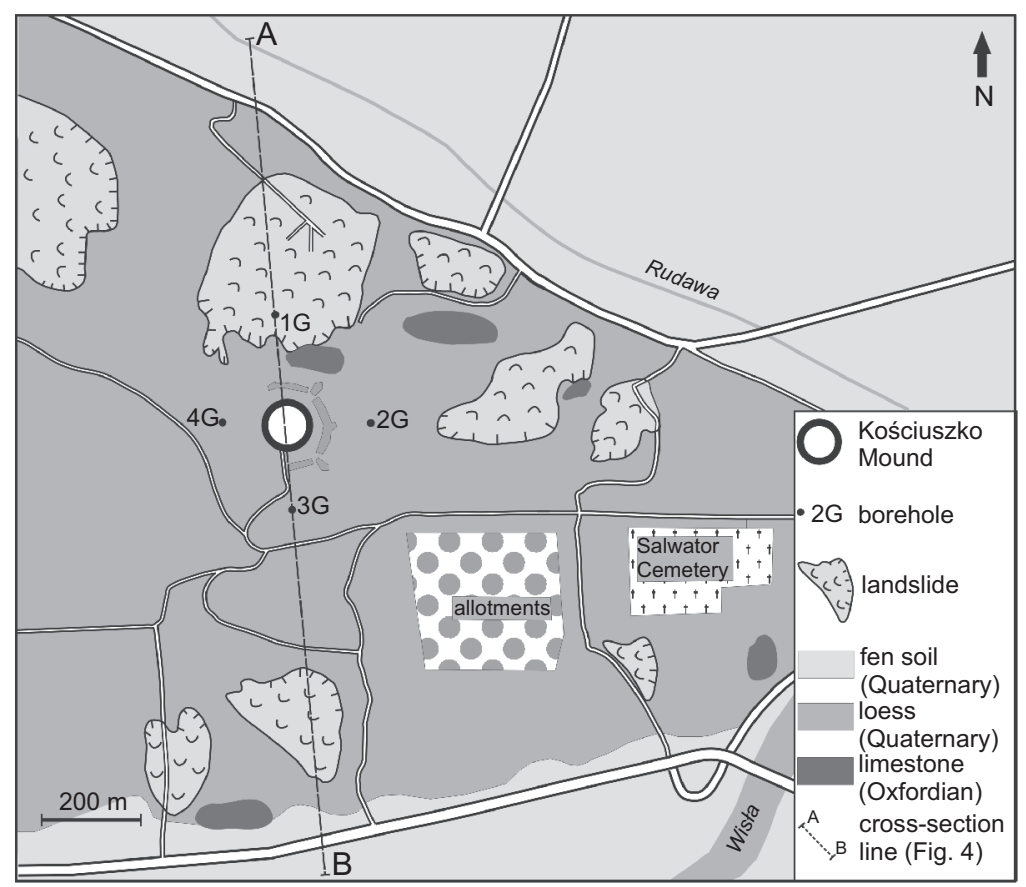

Fig. 2. Location of boreholes in the Kościuszko Mound area

sion of Upper Cretaceous sediments - therefore sediments of this age are found in the karst forms developed of the Upper Jurassic limestone. Younger sediments filling karst forms in older rocks according to Gradziński (1962) were earlier eroded and transported from land. The caves, which are now accessible, are related to the cutting of the limestone massif by deep valleys in the Late Miocene and Pliocene (Gradziński, 1962).

The existence of Cretaceous fillings in the Jurassic limestone in the Bonarka region (Kraków) was discussed by Wieczorek et al. (1995a, b), Dżułyński (1995) and Felisiak (1995). Wieczorek et al. (1995a, b) assumed that the fillings occurred in the submarine conditions, and they are neptunian dykes due to Late Cretaceous tectonics. Dżułyński (1995) and Felisiak (1995) concluded that the faults are of Paleogene age. Felisiak (1995) regarded the fill as a kind of clastic dykes formed by pressing of the overlying plastic Santonian marls into the widening tectonic crevices. Similar forms, described as injection dykes, have been found in anthropogenic outcrops near Pychowicka Street in Kraków (Kołodziej et al., 2010). Krobicki et al. (2008) suggested also earlier stages of origin of the neptunian dykes around Kraków, in the Oxfordian.

\section{MATERIAL AND METHODS}

The studied material came from four fully cored boreholes (each $100 \mathrm{~m}$ deep): 1G-4G (Fig. 3). Their location is shown in Figure 2. Cores were transferred to the municipal office of Kraków.

In all cases, white, creamy and creamy-greyish thick-bedded and massive limestones occur at a depth from 10 to $100 \mathrm{~m}$ under Quaternary sediments represented by loess or loess-like clay. Ten samples were taken for micropalaeontological investigation. Most of them came from the fillings of karst cavities in limestones. Two samples were collected from host limestones. Sampling depths are shown in Figure 3. Seven samples were taken for foraminiferal studies, and three samples for calcareous nannofossil investigations. Foraminiferal studies were performed on samples treated with water, washed and dried on an oven. Smear slides for nannofossil investigations were prepared according to the standard method described by Báldi-Beke (1984). Fine water suspension of the rock is spread out on the microscope slide after

probably of anthropogenic origin. On the Sowiniec Horst, Tynieckie Hills and Twardowski Rocks, situated south of the Vistula River valley, about twenty caves and shelters have been identified. Kowalski (1951) and Gradziński (1962) discussed the earlier views on karst processes in the southern part of the Kraków Upland. There are two views that suggest that the intense karst development took place during the Paleogene (Różycki, 1960) or Neogene, and Quaternary (Klimaszewski, 1958). The underground karst forms from the southern part of the Kraków Upland were studied by Gradziński (1962). He adopted the view that majority of the fossil karst channels were formed in the Early Paleogene and Late Neogene, during erostirring and a short period of settling. After drying, the microscope slide is covered with Canada balsam and a cover glass. The slides were inspected with a Nikon Eclipse E400Pol light microscope at 1000x magnification, and photographed using a DS-Fi1 Nikon camera.

\section{RESULTS}

The upper parts of the sections studied are strongly karstificated and cavernous. Caverns are frequently filled with 


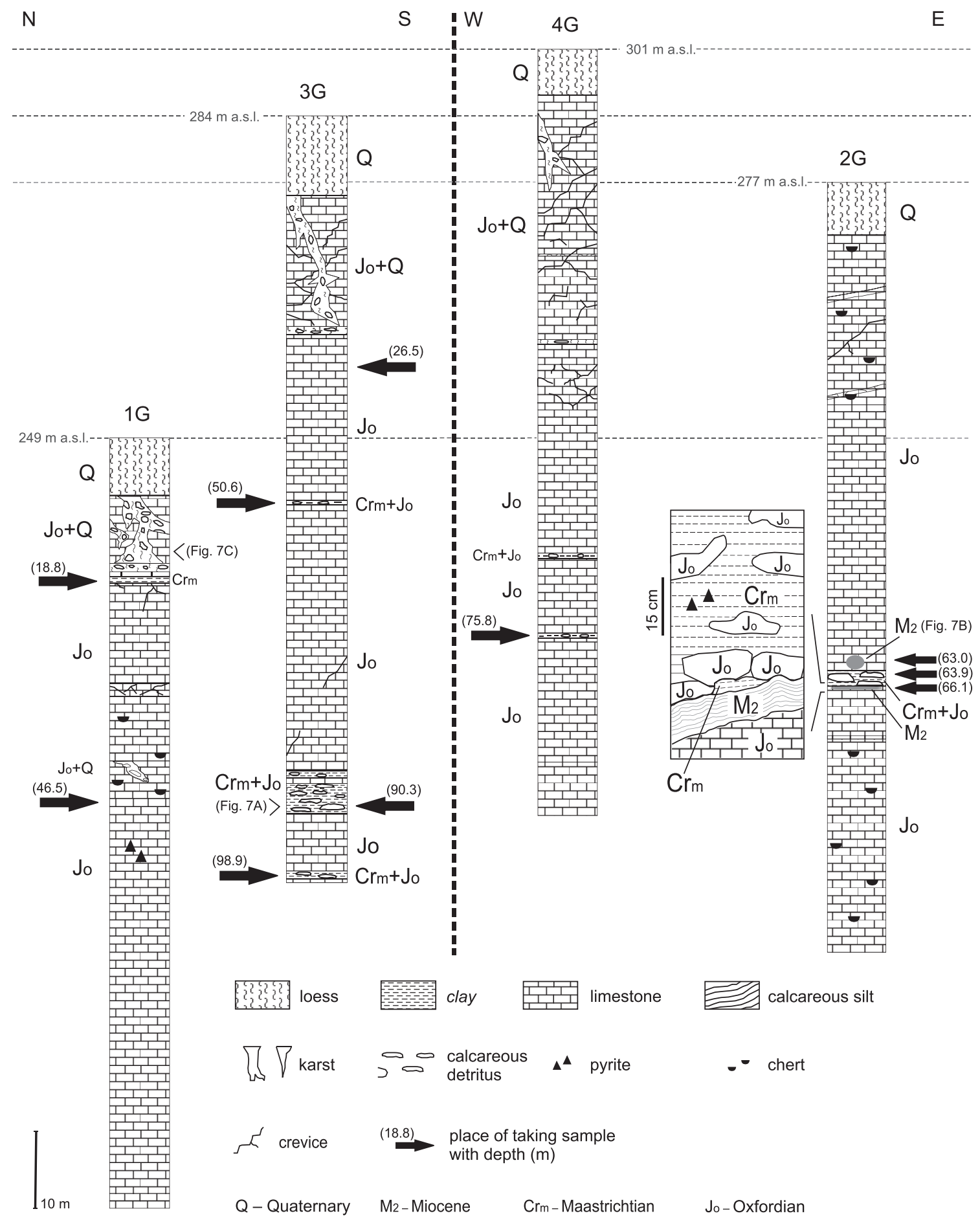

Fig. 3. Lithostratigraphic sections of the $1 G-4 G$ boreholes

calcite crystals. Light beige marly silt fills rare interlayer spaces. The limestones from the lower part of the boreholes are darker, creamy-grey and less weathered. Their specific colour is probably caused by admixture of pyrite (Dżułyński and Żabiński, 1954). Piryte crystals were found in a cavern at a depth of $55 \mathrm{~m}$. Numerous point precipitations or dendrites of manganese hydroxides and sutural joints (stylolites) occur locally within the limestones. Chert concretions coated by a white porous crust are randomly distributed in the limestone (Fig. 3). No distinct boundaries between the layers (with or without cherts) have been observed in the boreholes.

The results of micropalaeontological analysis (foraminifera, calcareous nannofossils) are presented in Table 1 and in Figures 5 and 6 . The $46.5 \mathrm{~m}$ depth sample from the $1 \mathrm{G}$ borehole contained only isolated specimens of the long-ranging foraminifer genera Rumanolina seiboldi. The Oxfordian foraminifera assemblage was found in the $3 \mathrm{G}$ borehole at a depth of $26.5 \mathrm{~m}$. Three different types of deposits have been recog- 
$\mathrm{N}$

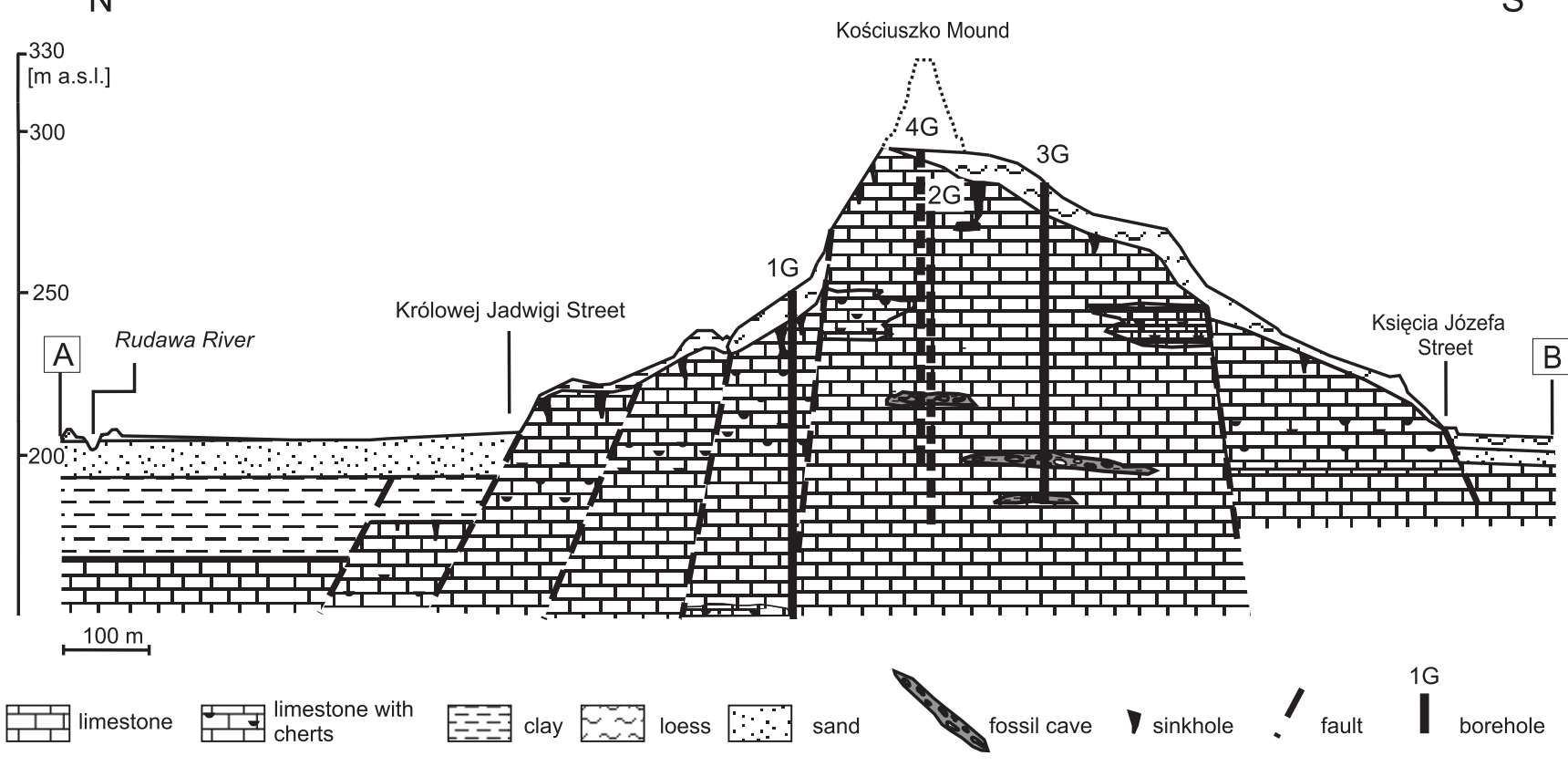

Fig. 4. Cross-section of the St. Bronisława Hill

nized: greenish-grey clays with calcareous, locally stratified, debris (Late Cretaceous in age), grey calcareous silts with planar lamination (Middle Miocene), and loess-like grey and tan-coloured silts with calcareous debris (Quaternary).

\section{GREENISH-GREY CLAYS WITH CALCAREOUS DEBRIS}

Greenish-grey clays with calcareous debris were found within the limestones in the $2 \mathrm{G}, 3 \mathrm{G}$ and $4 \mathrm{G}$ boreholes (Fig. 3). In the $1 \mathrm{G}$ borehole (depth 18.8-18.9 m), similar clays do not contain calcareous debris, which may be due to their small thickness. Clays enclosed in Jurassic rocks, recognized in the boreholes from the middle part of St. Bronisława Hill, contained traces of planar bedding. Clays usually comprised weakly rounded or sharp-edged calcareous pebbles (from a few milimetres to $10 \mathrm{~cm}$ long), elongated and irregular in shape (Fig. $7 \mathrm{~A}$ ). The longer axes of the pebbles are parallel to the bedding. The clays attain the greatest thickness in the $3 \mathrm{G}$ borehole, where an almost $4 \mathrm{~m}$ thick layer of greenish clay with calcareous debris (Fig. 3) occurs below a depth of $87.7 \mathrm{~m}$. In the sample from this borehole, a diversified Maastrichtian foraminifer assemblage was found. Furthermore, numerous sponge elements, ostracods and calcareous concretions were found in the assemblage. The same age is concluded for the assemblage obtained from the pyrite-rich clays in the $2 \mathrm{G}$ borehole, at the depth $63.9 \mathrm{~m}$. In the $3 G$ borehole, only poorly preserved, long-ranging foraminifers were identified at a depth of $90.3 \mathrm{~m}$ in light grey clays. Deeper in this borehole section, in the sample from a depth of $98.9 \mathrm{~m}$, the identified foraminiferal species and characteristic numerous sponge elements indicate Campanian-Maastrichtian age (Fig. 6 and Table 1). The same age is concluded for a foraminiferal assemblage found in the $4 \mathrm{G}$ borehole at a depth of $75.8 \mathrm{~m}$. The sample from $50.6 \mathrm{~m}$ depth in the
$3 G$ borehole contains residual, poorly preserved (due to mechanical deformation, dissolution and secondary calcitization) and rare calcareous nannofossils that indicate Late Cretaceous (Campanian-Maastrichtian) age.

\section{GREY CALCAREOUS SILTS WITH PLANAR LAMINATION}

An oval structure, differing from the surrounding light Jurassic limestones, filled with distinctly laminated calcareous silt, was observed in the $2 \mathrm{G}$ borehole at a depth of $62.8 \mathrm{~m}$ (Fig. 3). This structure is $25 \mathrm{~cm}$ high and its width exceeds that of the core diameter (i.e. $10 \mathrm{~cm}$ ). The thickness of the light and dark grey laminae is $1-8 \mathrm{~mm}$ (Fig. 7B). They have a horizontal and slightly sinuous arrangement. Particular laminae are bent upwards, suggesting a greater size of the structure filled by smaller channels. One of the channels ( $\sim 2 \mathrm{~cm}$ across) can be observed on the side of the structure.

The sample of laminated mudstones from a depth of $63.0 \mathrm{~m}$ and the sample from grey laminated deposits situated between the Cretaceous clays and Jurassic limestones, from a depth of $66.1 \mathrm{~m}$, yielded an Early Badenian calcareous nannofossil association. It is dominated by long-ranging placoliths (Coccolithus, small Reticulofenestra), tolerant to adverse environmental conditions, and less common shallow-water, nearly nearshore helicoliths (Helicosphaera) and cribriliths (Pontosphaera). According to Švabenicka (2002) and Báldi-Beke (1982), Helicosphaera prefers unstable environments that can be associated with the beginning of transgression, whereas Pontosphaera requires more stable environmental conditions and only slight fluctuation in salinity (Melinte, 2005). Important for the Middle Miocene stratigraphy, Sphenolithus heteromorphus and Discoaster variabilis occur only as single specimens. Both Sphenoliths and Discoasters are the most resistant 
Tables 1

Foraminifers, calcareous nannofossils and other characteristic microfossils in the 1G-4G boreholes

\begin{tabular}{|c|c|c|c|c|c|c|c|}
\hline \multirow{4}{*}{$\begin{array}{l}\text { Microfossils: } \\
\text { foraminifera and others }\end{array}$} & \multicolumn{7}{|c|}{ Borehole } \\
\hline & \multicolumn{2}{|c|}{$1 G$} & $2 G$ & \multicolumn{3}{|c|}{$3 G$} & $4 G$ \\
\hline & \multicolumn{7}{|c|}{ depth $[\mathrm{m}]$} \\
\hline & 18.8 & 46.5 & 63.9 & 26.5 & 90.3 & 98.9 & 75.8 \\
\hline $\begin{array}{l}\text { Abathomphalus } \\
\text { mayaroensis }\end{array}$ & & & $x$ & & & & \\
\hline Ammobaculites sp. & & $x$ & & & & & \\
\hline Arenobulimina sp. & $x$ & & & & & $x$ & \\
\hline Astrorhizidae family & & & & & $x$ & & \\
\hline Cibicides bembix & $x$ & & & & & & \\
\hline Cibicides sp. & & & $x$ & & & & \\
\hline Crescentiella morronensis & & & & $x$ & & & \\
\hline Gavelinella sp. & $x$ & & & & & & \\
\hline Globigerinelloides asperus & $x$ & & $x$ & & & & $x$ \\
\hline Globigerinelloides sp. & & & & & & $x$ & \\
\hline Globorotalites michelinianus & $x$ & & & & & & \\
\hline Globotruncana arca & & & & & & $x$ & \\
\hline Globotruncana linneiana & $x$ & & & & & & \\
\hline Globotruncana lapparenti & $x$ & & & & & & \\
\hline Glomospira sp. & & & $x$ & & $x$ & & \\
\hline Gyroidinoides nitidus & $\mathrm{x}$ & & & & & $x$ & $x$ \\
\hline Hedbergella sp. & & & $x$ & & & & $x$ \\
\hline Heterohelix globulosa & & & & & & $x$ & $x$ \\
\hline Lenticulina sp. & & $x$ & & & & & \\
\hline $\begin{array}{l}\text { Rugoglobigerina } \\
\text { macrocephala }\end{array}$ & $\mathrm{x}$ & & & & & & \\
\hline Rugoglobigerina rugosa & & & & & & $x$ & \\
\hline Rugoglobigerina sp. & & & $x$ & & & & \\
\hline Spirillina sp. & $x$ & & & $x$ & & & $x$ \\
\hline $\begin{array}{l}\text { Spiroplectammina } \\
\text { navarroana }\end{array}$ & $x$ & & & & & & \\
\hline Stensioeina aff. gracilis & & & & & & & $x$ \\
\hline Terebella lapilloides (worms) & & & & $x$ & & & \\
\hline bivalves & & & & $x$ & & & \\
\hline bryozoans & & $x$ & & & & & \\
\hline echinoids' spines & & & $x$ & & & & \\
\hline calcareous sponges & $x$ & $x$ & $x$ & & & $x$ & \\
\hline $\begin{array}{l}\text { micromummies of the } \\
\text { siliceous sponges }\end{array}$ & $x$ & $x$ & $x$ & & & $x$ & \\
\hline ostracods & $x$ & & & & & & \\
\hline radiolarians & & & $x$ & & & & \\
\hline
\end{tabular}

\begin{tabular}{|c|c|c|c|}
\hline \multirow{4}{*}{ Calcareous nannofossils } & \multicolumn{3}{|c|}{ Borehole } \\
\hline & \multicolumn{2}{|c|}{$2 \mathrm{G}$} & $3 G$ \\
\hline & \multicolumn{3}{|c|}{ depth [m] } \\
\hline & 63.0 & 66.1 & 50.6 \\
\hline Arkhangelskiella sp. & & & $x$ \\
\hline $\begin{array}{l}\text { Braarudosphaera cf. } \\
\text { bigelowii }\end{array}$ & $x$ & $x$ & \\
\hline Braarudosphaera bigelowii & $x$ & $x$ & $x$ \\
\hline Calculites obscurus & & & $x$ \\
\hline Coccolithus pelagicus & $x$ & $x$ & \\
\hline Cyclicargolithus floridanus & & $x$ & \\
\hline Dictyococcites aff. bisectus & & $x$ & \\
\hline Discoaster cf. variabilis & & $x$ & \\
\hline Eiffellithus eximius & $x$ & & $x$ \\
\hline Ericsonia formosa & $x$ & & \\
\hline Helicosphaera carteri & $x$ & $x$ & \\
\hline $\begin{array}{l}\text { Helicosphaera } \\
\text { walbersdorfensis }\end{array}$ & $x$ & & \\
\hline Helicosphaera sp. & $x$ & $x$ & \\
\hline Lucianorhabdus cayeuxii & & & $x$ \\
\hline Lucianorhabdus maleformis & & & $x$ \\
\hline Micula decussata & $x$ & $x$ & $x$ \\
\hline Micula swastica & & & $x$ \\
\hline Micula sp. & & $x$ & $x$ \\
\hline Pontosphaera multipora & $x$ & $x$ & \\
\hline $\begin{array}{l}\text { Prediscosphaera aff. } \\
\text { cretacea }\end{array}$ & & & $x$ \\
\hline Prediscosphaera cretacea & $x$ & & $x$ \\
\hline Reticulofenestra hillae & & $x$ & \\
\hline $\begin{array}{l}\text { Reticulofenestra sp. } \\
\text { (small forms) }\end{array}$ & $x$ & $x$ & \\
\hline $\begin{array}{l}\text { Sphenolithus } \\
\text { heteromorphus }\end{array}$ & $x$ & $x$ & \\
\hline Umbilicosphaera rotula & $x$ & & \\
\hline Uniplanarius gothicus & & & $x$ \\
\hline Uniplanarius sissinghii & & & $x$ \\
\hline Watznaueria barnesae & $x$ & & \\
\hline Watznaueria sp. & & $x$ & $x$ \\
\hline
\end{tabular}

to dissolution (Bukry, 1981), but sensitive to high fluctuation in salinity. The scarcity of these species in the analysed samples may be due to the generally poor state of preservation of most of the identified forms or unfavourable (especially for discoasters) environmental conditions. In both samples, poorly preserved, destroyed and scarce redeposited Eocene-Oligocene (Dictyococcites aff. bisectus, Ericsonia formosa, Reticulofenestra hillae) and Upper Cretaceous species were identified, but due to the poor preservation, their quantity is impossible to estimate.

\section{GREY AND TAN-COLOURED LOESS-LIKE SILTS WITH THE CALCAREOUS DEBRIS}

The deposits occur in the top part of the cored section (Fig. 3 ) and are the most frequent in the $1 \mathrm{G}$ borehole down to a depth of $20.0 \mathrm{~m}$. This borehole was drilled about $200 \mathrm{~m}$ north of the Kościuszko Mound, probably through a karst sinkhole. Fragments of the limestone (from a few centimetres to more than $10 \mathrm{~cm}$ across) are distributed randomly in loam of the upper part 

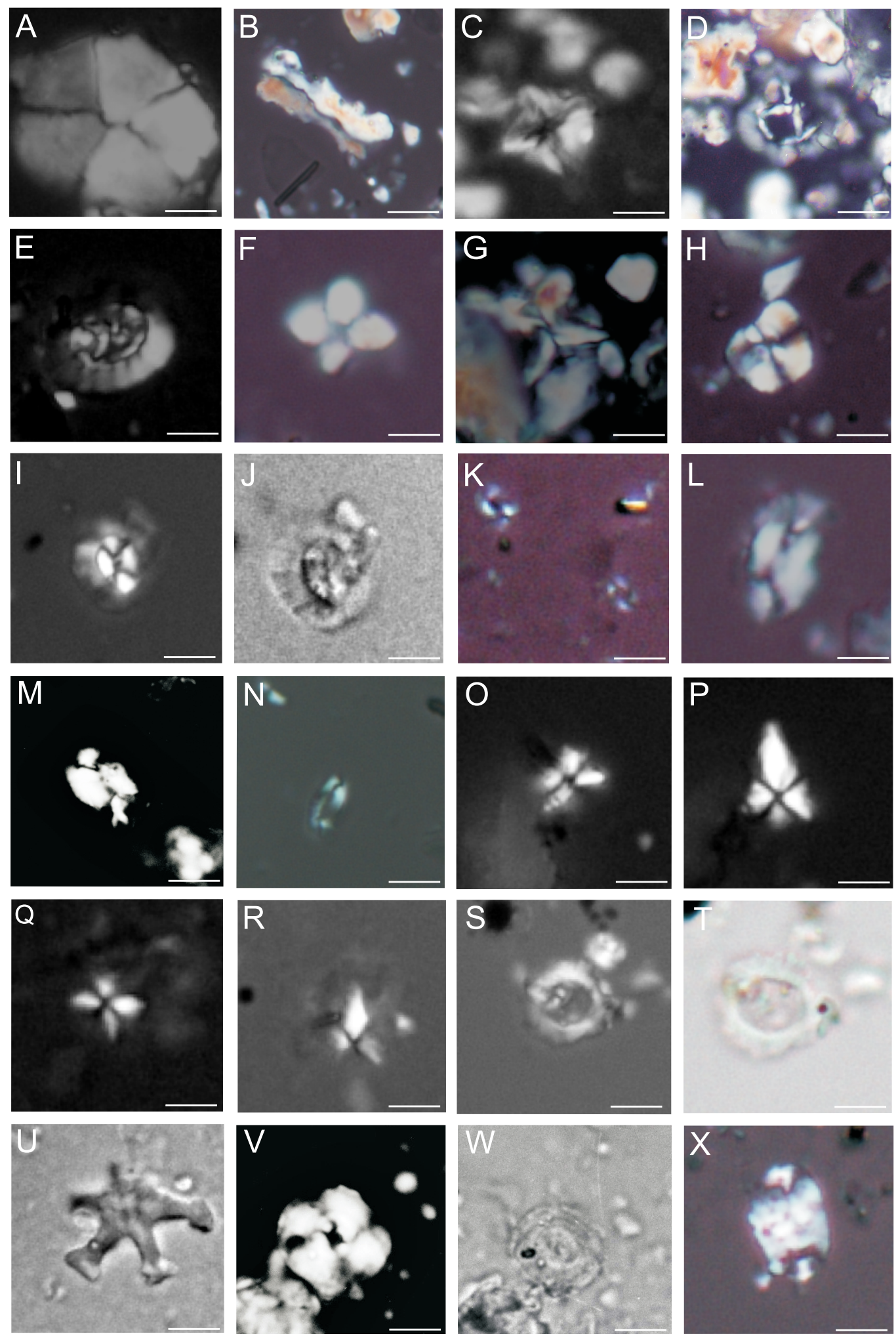

Fig. 5. Calcareous nannoplankton in the boreholes: $2 \mathrm{G}$ (depth $63.0 \mathrm{~m}$ : I-T and $66.1 \mathrm{~m}$ : U-X) and $3 \mathrm{G}$ (depth $50.6 \mathrm{~m}: \mathrm{A}-\mathrm{H}$ )

A - Braarudosphaera bigelowii (Gran et Braarud) Deflandre - CN; B - Lucianorhabdus cayeuxii Deflandre - CN; C - Micula decussata Vekshina - CN; D - Prediscosphaera aff. ponticula (Bukry) Perch-Nielsen - CN; E - Prediscosphaera cf. cretacea (Arkhangelsky) Gartner - CN; F - Uniplanarius gothicus (Deflandre) Hattner et Wise - CN; G - Uniplanarius sissinghii Perch-Nielsen - CN; H - Watznaueria sp. - CN; I - Coccolithus pelagicus (Wallich) Schiller - CN; J - Coccolithus pelagicus (Wallich) Schiller - NL; K - small Reticulofenestrids - CN; L - Helicosphaera carteri (Wallich) Kamptner - CN; M - Helicosphaera carteri (Wallich) Kamptner CN; N - Helicosphaera walbersdorfensis Müller - CN; O - Sphenolithus heteromorphus Deflandre - CN $0^{\circ} ; \mathbf{P}-$ Sphenolithus heteromorphus Deflandre - CN $45^{\circ} ; \mathbf{Q}$ - Sphenolithus heteromorphus Deflandre - CN $0^{\circ} ; \mathbf{R}-$ Sphenolithus heteromorphus Deflandre - CN 45; S - Umbilicosphaera rotula (Kamptner) Varol - CN; T - Umbilicosphaera rotula (Kamptner) Varol - NL; U - Discoaster cf. variabilis Martini et Bramlette - NL; V - Cyclicargolithus floridanus (Roth et Hay) Bukry - CN; W - Cyclicargolithus floridanus (Roth et Hay) Bukry - NL; $\mathbf{X}$ - Pontosphaera cf. multipora (Kamptner) Roth - CN; CN - crossed polars, NL - normal light, scale bar is $5 \mu \mathrm{m}$ 

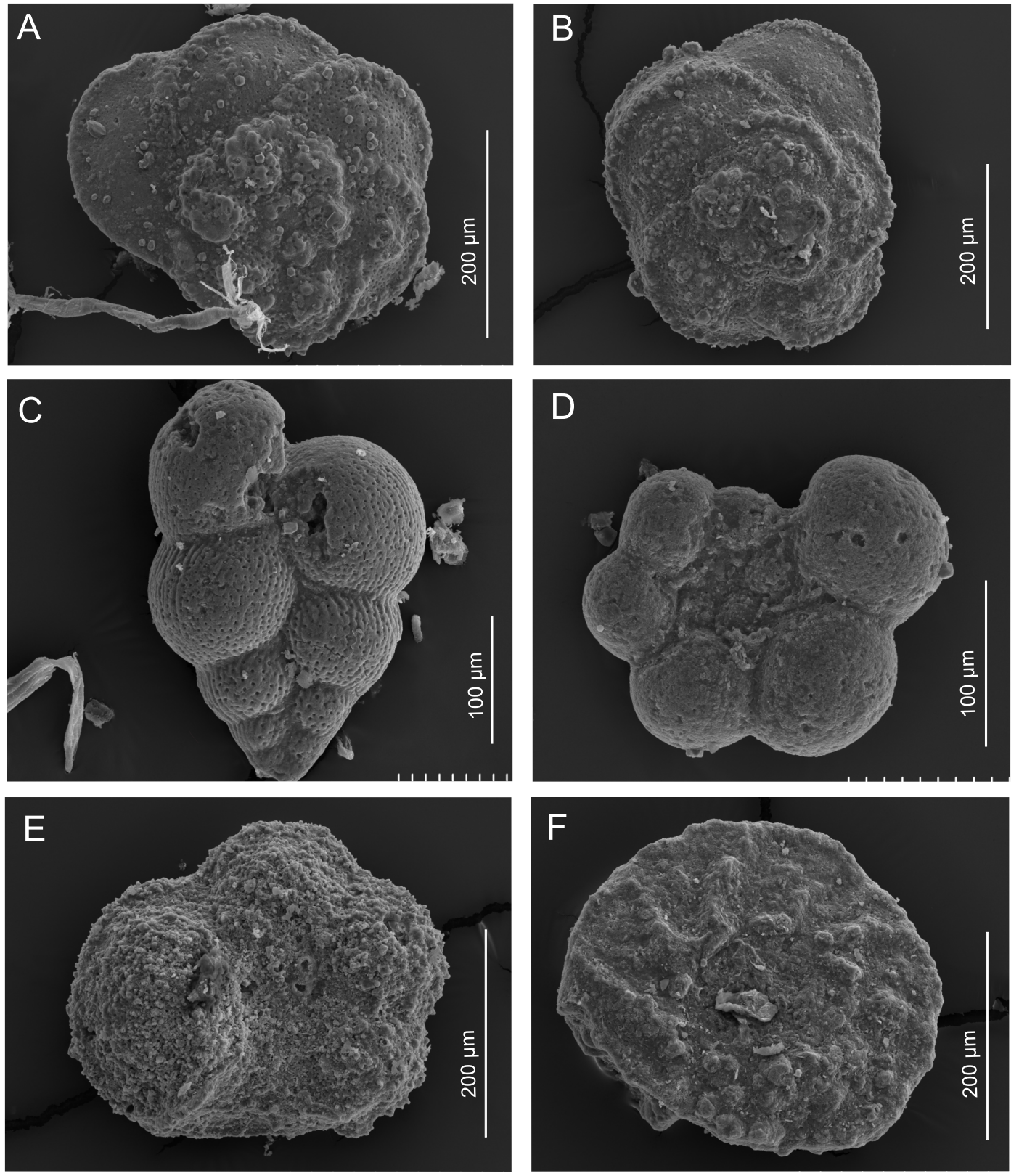

Fig. 6. Some Late Cretaceous foraminifers from the boreholes in the Kościuszko Mound area

A - Globotruncana arca (Cushman), dorsal side, 2G borehole, depth $63.0 \mathrm{~m}$; B - Abathomphalus mayaroensis (Bolli), dorsal side, 2G borehole, depth $63.9 \mathrm{~m}$; C - Heterohelix globulosa (Ehrenberg), side view, 3G borehole, depth $98.9 \mathrm{~m}$; D - Globigerinelloides asperus (Ehrenberg), side view, 2G borehole, depth $63.9 \mathrm{~m}$; E Rugoglobigerina sp., ventral side, 2G borehole, depths 63.9 m; F - Stensioeina cf. exculpta (Reuss), dorsal side, $2 \mathrm{G}$ borehole, depths $63.0 \mathrm{~m}$

of the $1 \mathrm{G}$ borehole (Fig. 7C). They are weakly rounded and sharp-edged. Below a depth of $16.5 \mathrm{~m}$, the light brown loam is replaced by grey silt. In the other borehole $(2 \mathrm{G}-4 \mathrm{G})$, the karst fissures have various sizes and are frequently funnel-like. The smallest fissures are a few centimetres across while the largest ones may attain a few metres. The size of calcareous debris varies from a few to more than ten centimetres. No microfaunal study was performed on the grey and tan-coloured loess.

\section{INTERPRETATION AND DISCUSSION}

The Upper Jurassic limestones from the area of the Kościuszko Mound were deposited in a shallow, warm sea on the northern shelf of the Tethys Ocean (Trammer, 1982). These were good conditions for developing cyanobacteria-sponge bioherms (Dżułyński, 1952; Matyszkiewicz, 1989; Heliasz, 1996) 


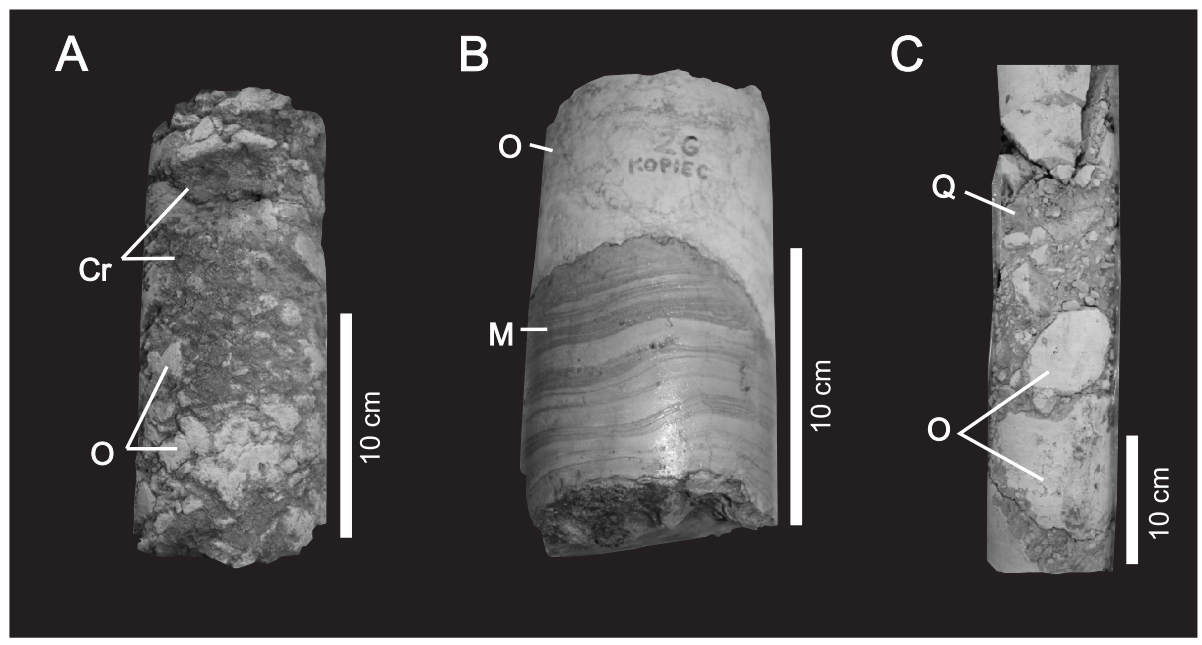

Fig. 7. Sediments filling fossil karst forms

A - greenish-grey clays with calcareous debris in the 3G borehole (depth 90.4-90.6 m); $\mathrm{Cr}-\mathrm{Up}$ per Cretaceous clays, O - Oxfordian limestone debris; B - Miocene calcareous silts filling the cavity within Oxfordian limestones; $2 \mathrm{G}$ borehole (depth 62.8-62.95 m); O - Oxfordian limestone, $\mathrm{M}$ - Middle Miocene calcareous silts; $\mathbf{C}$ - tan loess with calcareous debris; $1 \mathrm{G}$ borehole (depth 14.5-14.9 m); Q - Quaternary loess, O - Oxfordian limestone debris

resulting in the formation of massive limestones that make up the major part of the borehole sections. Irregular distribution of cherts in the non-bedded limestone from some sections of drill cores may be due to drilling through the transition zone between the bedded limestone with cherts and the massive limestone. Such transitions are visible in many places of the Kraków Upland (e.g., Piekary Quarry and Jeziorzany). The Upper Jurassic limestones underwent repeated emergence from the water and were subjected to karstification. The Upper Cretaceous greenish grey clays, Middle Miocene laminated limestones, and Quaternary loess with calcareous debris fill the fossil karst structures.

Gradziński (1962) considered that the clays, containing Late Cretaceous fossils that occur within the limestones in the area of Kraków, come from erosion of marls and are redeposited to different forms of karst. They usually fill karst pits, near which there are exposures of Cretaceous marls. Similar green clays filling fossil caves are included by Felisiak (1992) in the "category of Oligocene-Early Miocene karst deposits". Upper Cretaceous sediments within the Jurassic limestones in the Kraków area were also considered as clastic dykes (Dżułyński, 1995; Felisiak, 1995), neptunian dykes (Wieczorek et al., 1995a, b; Krobicki et al., 2008) or injection dykes (Kołodziej et al., 2010). Cretaceous sediments within the Jurassic limestone were also found in the Gdów area, about $25 \mathrm{~km} \mathrm{E}$ of Kraków (Połtowicz, 1962), where they are at a depth of about $200 \mathrm{~m}$ from the top of limestone. Poltowicz (1962) interpreted them as a result of reverse faults.

Data from the boreholes in the Kościuszko Mound area suggest that the Upper Cretaceous clays fill the fossil karst channels and caves. St. Bronisława Hill as well as the entire horst of the Wolski Forest have the character of a wide and flattened hump, where no Upper Cretaceous deposits have been found on the surface. In addition, there are no Maastrichtian deposits in the immediate vicinity of Kraków. Greenish-grey clays in the basement of the Kościuszko Mound occur well below the Rudawa valley level (Fig. 4). The fillings of fossil karst forms from the area of Kraków, described in the literature, are often represented by sandy-clay sediments (Gradziński 1962; Felisiak, 1992), among others clays layered sand (Alexandrowicz, 1969). The presence of sand indicates that the clays could be locally eroded by surface waters and resedimented. The karst forms in the basement of the Kościuszko Mound do not contain sands. Due to the above, another possibility than redeposition of Cretaceous material in these very deep karst forms (Figs. 3 and 4) is also plausible. The position of the material studied is not a result of tectonic movements, especially because the manifestations of tectonic movements are poor in the obtained cores. The faults identified are younger than the sediments filling the karst channel systems. In the case of Cretaceous sediments in the St. Bronisława Hill area, the concept of neptunian dykes (Wieczorek et al., 1995a, b; Krobicki et al., 2008; Kołodziej et al., 2010) cannot be considered due to the depth of the occurrence of Upper Cretaceous sediments within Jurassic rocks. All forms described as neptunian dykes have been observed in the upper part of limestones.

The origin of the karst system and its fill in the basement of the Kościuszko Mound has not been fully explained yet. The authors do not exclude the possibility that the channels developed during intense karst processes in the Paleogene or Neogene, but they could also form in subaerial conditions during the Late Jurassic and Early Cretaceous lowering of the sea level (cf. Haq et al., 1988). Tithonian-Cenomanian times were among the major periods of karstification in southern Poland, however, few forms have been preserved and documented (Głazek, 1989); most of them were destroyed during the subsequent transgression. The channel system may have formed also as a result of elevation of the limestone massifs above the sea level, which enabled development of karst. Karst channel filling might have occurred during the Late Cretaceous submergence (Campanian-Maastrichtian). During the filling process, there was a slow disintegration of the upper part of the karst channels, as indicated by rubble limestone occurring within the clays derived from rockfall from the ceiling of the caves. Another possibility is that the channels originated as a result of submarine karst in the coastal shelf. Drainage of the fresh-water to submarine zones and infiltration of the salt water into the cracks and their penetration into the land causes mixing of waters of different origin, making them more aggressive (Herak, 1972; Ford and Williams, 2007). Today, the development of karst is observed in many submarine karst systems including the Gulf of Mexico, Bermuda, Sardinia and Croatia (Carobenne 
and Pasini, 1980; Airoldi and Cinelli, 1996; Surić, 2002; Hengstum et al., 2011). In submarine caves occurring near the high sea coasts, sands are also deposited during storms.

The Middle Miocene laminated calcsiltite channel-fills and small karst forms, found at the base of the Kościuszko Mound (Fig. 3), may also be the result of submarine sedimentation. Miocene deposits of this type, filling fossil karst forms, were not previously known from the area of Kraków. Development of channels that are even less than $60 \mathrm{~m}$ from the top of the limestone was probably supported by crevices associated with Neogene tectonics. Karst channels could grow along the walls of horsts that were emerged before the Middle Miocene transgression (Dżułyński, 1953). It is unlikely that sedimentation of laminated calcsilite of Miocene age, containing marine fauna, took place in terrestrial conditions as a result of erosion and transport of sediment from the overburden. A channel visible in the $2 \mathrm{G}$ borehole at the depth of $66.1 \mathrm{~m}$ formed at the boundary of soluble limestone and less soluble Cretaceous clays. It gave the effect of filling of the karst cavity by two different generations. Unclear is the presence of redeposited Paleogene nannoplankton forms in the samples. Today, such sediments are not found within the study area. For this period creation of the Paleogene planation surface is assumed (Alexandrowicz, 1969). It would indicate erosion and transport of marine Paleogene sediments from an area located north of horst of the Wolski Forest, as the transport from the distant Carpathian area seems unlikely.

Quaternary deposits with Jurassic calcareous debris occur mainly to a depth of $10 \mathrm{~m}$ below ground level. The absence of rounding of pebbles indicates a short transport and rapid redeposition. Their irregular distribution in the Quaternary loess covering limestones, clearly indicates that they are the filling of sinkholes. They were formed rapidly due to the collapse of the ceiling of caves in strongly karstified limestones. The funnel-shaped structures of smaller size usually developed along the crevices. They are often fuzzy fault crevices filled with karst-derived material and tectonic breccias.

\section{CONCLUSIONS}

New data from the region of the Kościuszko Mound enabled a new interpretation of Upper Cretaceous and Miocene deposits filling the karstic systems in the Jurassic limestones of the Kraków region. It is suggested that these sediments are associated with the submarine filling of fossil karst forms. The development of karst in this area began in the Cretaceous and occurred in several stages: before the Late Cretaceous, during the Paleogene-Neogene, and during the Quaternary.

Fossil karst forms filled with Cretaceous sediments have been found within the Jurassic limestone. They occur even $100 \mathrm{~m}$ below the present ground surface. These forms may have been created during the emersion of limestones before the Late Cretaceous. Filling of the karst channels may have took place during the Campanian-Maastrichtian.

Within the limestones drilled around the Kościuszko Mound, a few karst forms filled by Middle Miocene laminated limestones have been recognized. Calcsiltites reached the Jurassic limestones through the system of karst channels. They could develop along the horst walls and accumulated deposits of less than 60 metres below the present ground surface. Deposits of this type filling the fossil karst were not previously known from the area of Kraków.

Karst forms situated nearest to the ground surface are the crevices and sinkholes filled by Quaternary deposits.

Acknowledgements. We are grateful to the reviewers Dr. M. Oszczypko-Clowes and Dr. M. Gradziński (both Jagiellonian University, Institute of Geological Sciences, Kraków) and Dr. K. Žecová (Štátny Geologický Ústav D. Štúra, Bratislava) for their critical reading of the manuscript, and for remarks that significantly improved the paper.

\section{REFERENCES}

Airoldi, L., Cinelli, F., 1996. Variability of fluxes of particulate material in a submarine cave with chemolithoautotrophic inputs of organic carbon. Marine Ecology, 139: 205-217.

Alexandrowicz, S.W., 1969. Couches de Paléogène de la partie méridionale du Plateau de Cracovie (in Polish with French summary). Rocznik Polskiego Towarzystwa Geologicznego, 39: 681-696.

Báldi-Beke, M., 1982. Helicosphaera mediterranea Müller 1981, and its stratigraphical importance in the Lower Miocene. International Nannoplankton Association Newsletter, 4: 104-106.

Báldi-Beke, M., 1984. The nannoplankton of the Transdanubian Palaeogene Formations. Geologica Hungarica, Ser. Palaeontologia, 43: 3-307.

Baryła, J., Szelerewicz, M., 2011. Schronisko pod Klasztorem Norbertanek (in Polish). In: Jaskinie Pomostu Krakowskiego. Praca zbiorowa (ed. J. Grodzicki): 97. Polskie Towarzystwo Przyjaciół Nauk o Ziemi, Warszawa.

Bromley, R.G., Kedzierski, M., Kołodziej, B., Uchman, A., 2009 Large chambered sponge borings on a Late Cretaceous abrasion platform at Cracow, Poland. Cretaceous Research, 30: 149-160.

Bukry, D., 1981. Cenozoic coccoliths from the Deep Sea Drilling Project. SEPM Special Publication, 32: 335-353.
Carobene, L., Pasini, G., 1980. Some notes on the Pleistocene and Holocene of the Gulf of Orosei (Eastern Sardinia) (in Italian with English summary). Bollettino Della Societa' Adriatica Di Scienze, 64: 5-36.

Dżułyński, S., 1952. The Origin of the Upper Jurassic Limestones in the Cracow Area (in Polish with English summary). Rocznik Polskiego Towarzystwa Geologicznego, 21: 125-180.

Dżułyński, S., 1953. Tectonics of the southern part of the Cracow Upland (in Polish with English summary). Acta Geologica Polonica, 3: 325-440.

Dżułyński, S., 1995. Neptunian dykes of Bonarka - a testimony of the Late Cretaceous tectonic movements in the Cracow Upland - discussion (in Polish with English summary). Przegląd Geologiczny, 43: 689 .

Dżułyński, S., Żabiński, W., 1954. Ciemne wapienie w jurze krakowskiej (in Polish). Acta Geologica Polonica, 4: 181-190.

Felisiak, I., 1992. Oligocene-early Miocene karst deposits and their importance for recognition of the development of tectonics and relief in the Carpathian Foreland, Kraków region, Southern Poland (in Polish with English summary). Annales Societatis Geologorum Poloniae, 62: 173-207.

Felisiak, I., 1995. Neptunian dykes of Bonarka - a testimony of the Late Cretaceous tectonic movements in the Cracow Upland - 
discussion (in Polish with English summary). Przegląd Geologiczny, 43: 869-872.

Felisiak, I., Matyszkiewicz, J., Sokołowski, T., 2005. Teaching of geological mapping at Geological Mapping Department, AGH University of Science and Technology. Przegląd Geologiczny, 53: 899-902.

Ford, D., Williams, P., 2007. Karst Hydrogeology and Geomorphology. John Wiley and Sons Ltd.

Głazek, J., 1989. Paleokarst of Poland. In: Paleokarst, a Systematic and Regional Review. (eds. P. Bosák, D. Ford, J. Głazek and I. Horaček): 77-105. Academia, Prague.

Gradziński, M., Gradziński, R., Paszkowski, M., 1995. Two caliche horizons in Miocene deposits at Przegorzały in Kraków (in Polish with English summary). Przegląd Geologiczny, 43: 644-646.

Gradziński, R., 1962. Origin and development of subterranean karst in the southern part of the Cracow Upland (in Polish with English summary). Rocznik Polskiego Towarzystwa Geologicznego, 32: 429-490.

Gradziński, R., 1972. Przewodnik geologiczny po okolicach Krakowa (in Polish). Wyd. Geol., Warszawa.

Gradziński, R., 2009. Mapa Geologiczna Obszaru Krakowskiego w skali 1:100 000 (in Polish). Wyd. Muzeum Geologiczne. Instytut Nauk Geologicznych PAN, Kraków.

Haq, B., Hardenbol, J., Vail, P., 1988. Mesozoic and Cenozoic chronostratigraphy and cycles of sea-level change. SEPM Special Publication, 42: 71-108.

Heliasz, Z., 1996. Powstawanie wapieni skalistych - ewolucja pogladów (in Polish). XVI Terenowa Szkoła Geologów, Uniwersytet Śląski, Sosnowiec.

Hengstum, P., Scott, D., Gröcke, D., Charette, M., 2011. Sea level controls sedimentation and environments in coastal caves and sinkholes. Marine Geology, 286: 35-50.

Herak, M., 1972. Karst of Yugoslavia. In: Karst: Important Karst Regions of the Northern Hemisphere (eds. M. Herak and V.T. Stringfield): 25-83. Amsterdam, Elsevier.

Klimaszewski, M., 1958. Modern views on the development of the karstic relief (in Polish with English summary). Przegląd Geograficzny, 30: 423-438.

Kołodziej, B., Szulc, J., Machaniec, E., Kędzierski, M., Duda, M., 2010. Injection dykes as evidence of Campanian synsedimentary tectonics on the Kraków Swell, southern Poland. Annales Societatis Geologorum Poloniae, 80: 285-301.

Kos, J., Foryś, M., Rzepecki, D., Bartosz, L., Bakaj, M., Boroń, K., 2013. Dokumentacja geologiczno-inżynierska dla rozpoznania podłoża, dla potrzeb opracowania zabezpieczenia obiektu stożka Kopca Kościuszki wraz z otoczeniem, zniszczonego przez aktywne osuwisko Q-5521 (in Polish). Przedsiębiorstwo Geologiczne S.A., Kraków.

Kowalski, K., 1951. Jaskinie Polski, Jaskinie Wyżyny KrakowskoWieluńskiej (in Polish). Państwowe Muzeum Archeologiczne, Warszawa.
Krobicki, M., Golonka, J., Kucharski, J., 2008. Jurajskie i kredowe dajki neptuniczne w północnej Tetydzie i na obszarze peryTetydy - reperkusje geotektoniczne (in Polish). Geologia, 34: 185-188.

Łanczont, M., Madeyska, T., Mroczek, P., Hołub, B., Komar, M., Kusiak, J., Łącka, B., Żogała, B., Bogucki, A., 2013. Age and palaeoenvironmental history of loess cover in the area of the Kraków-Spadzista Street archeological site (southern Poland). In: Abstracts and Guide Book of International Conference World of Gravettian Hunters, Kraków, 25-28 czerwca 2013: 119-137.

Matyszkiewicz, J., 1989. Sedimentation and diagenesis of the Upper Oxfordian cyanobacterial-sponge limestones in Piekary near Kraków. Annales Societatis Geologorum Poloniae, 69: 201-232.

Melinte, M., 2005. Oligocene palaeoenvironmental changes in Romanian Carpathians, revealed by calcareous nannofossils. Studia Geologica Polonica, 124: 341-352.

Połtowicz, S., 1962. Tektonika północnego brzegu zatoki gdowskiej (in Polish). Sprawozdania z Posiedzeń Komisji Państwowej Akademii Nauk, Kraków: 451-456.

Różycki, S.Z., 1960. Jura górna i kreda oraz zjawiska krasowe w północnej części Wyżyny Krakowsko-Częstochowskiej (in Polish). In: Przewodnik XXXIII Zjazdu Polskiego Towarzystwa Geologicznego, Częstochowa, 4-6 września 1960 (ed. S.Z. Różycki): 28-50. Wyd. Geol., Warszawa.

Rutkowski, J., 1993. Objaśnienia do Szczegółowej Mapy Geologicznej Polski 1:50 000 Arkusz Kraków (973) (in Polish). Państwowy Instytut Geologiczny, Warszawa.

Słobodzian, B., 2011. Kawerna pod Fortem Kościuszko. In: Jaskinie Pomostu Krakowskiego (in Polish). Praca zbiorowa (ed. J. Grodzicki): 98-99. PTPNoZ, Warszawa.

Surić, M., 2002. Submarine karst of Croatia - evidence of former lower sea levels. Acta Carsologica, 5: 89-98.

Švabenicka, L., 2002. Calcareous nannofossils of the Middle Miocene deposits in the Carpathian Foredeep, Czech Republic. Geologica Carpathica, 53, Spec. Issue: 71-72.

Trammer, J., 1982. Lower to Middle Oxfordian sponges of the Polish Jura. Acta Geologica Polonica, 29: 39-49.

Tyczyńska, M., 1968. Geomorphological evolution of the city of Cracow (in Polish with English summary). Zeszyty Naukowe Uniwersytetu Jagiellońskiego, Prace Geograficzne, 17: 5-68.

Wieczorek, J., Dumont, T., Boullin, J., Olszewska, B., 1995a. Neptunian dykes of Bonarka - a testimony of the Late Cretaceous tectonic movements in the Cracow Upland - reply (in Polish with English summary). Przegląd Geologiczny, 43: 690-692.

Wieczorek, J., Dumont, T., Bouillin, J., Olszewska, B., 1995b. Neptunian dykes of Bonarka - a testimony of the Late Cretaceous tectonic movements in the Cracow Upland - reply (in Polish with English summary). Przegląd Geologiczny, 43: 872-875. 